\title{
Development of Tiers 2 and 3 methane emission factors for enteric fermentation and manure management of cattle and sheep using Hillsborough herd data and calorimetric methane measurements
}

T Yan, V B Woods, S J Morrison, F O Lively, R Annett, L E R Dawson, A Carson

Agri-Food and Biosciences Institute, Hillsborough, United Kingdom

Email: tianhai.yan@afbini.gov.uk

Introduction The Intergovernmental Panel on Climate Change (IPCC, 2006) recommends three methods (Tier 1, 2 and 3 ) to estimate methane $\left(\mathrm{CH}_{4}\right)$ emissions from enteric fermentation and manure management for livestock in development of national $\mathrm{CH}_{4}$ inventories. Tier 1 default emission factors (enteric and manure) provide fixed values for each species of animals in different regions of the World, irrespective of variations in animal physiological state and production level. The objectives of the present study were to develop $\mathrm{CH}_{4}$ emission factors of Tiers 2 (enteric and manure) and 3 (enteric) using AFBI Hillsborough herd data and calorimeter $\mathrm{CH}_{4}$ measurements and to identify sources of variations between Tier 1 and Tier $2 / 3$ emission factors.

Materials and methods AFBI Hillsborough herd data used include average live weight, milk yield (7328 kg/year, dairy cows), growth rate (growing animals), birth rates (cows, heifers and ewe), age (growing animals) and dietary GE, ME and ash concentrations for each species. Calorimetric $\mathrm{CH}_{4}$ and energy metabolism data included measurements undertaken at Hillsborough since 1992 with more than 900 dairy cows, 140 beef and 50 sheep. The life span for lambs was taken as 210 days. Manure was managed under the liquid/slurry system for indoor feeding animals and the pasture management system for grazing animals. Tier $2 \mathrm{CH}_{4}$ emission factors from enteric fermentation and manure management were developed using the methodologies proposed by IPCC (2006). Tier 3 enteric $\mathrm{CH}_{4}$ emission factors were developed from the ratio of $\mathrm{CH}_{4}$ energy output to ME intake, with ME intake estimated using the FiM models for dairy cows and AFRC systems for beef cattle, heifers and sheep.

Results and discussion The results are presented in Table 1. For enteric $\mathrm{CH}_{4}$ emissions, Tiers 2 and 3 factors for dairy cows were 10.2 and $7.5 \mathrm{~kg} /$ year lower than Tier 1 factor, respectively. This indicates that the increase in Tier 1 default factor for Western Europe from $100 \mathrm{~kg} /$ year in the version of IPCC 1996 to the present $117 \mathrm{~kg} / \mathrm{year}$ (IPCC, 2006) may over-estimate the effect of increased milk production during the period. For sheep, dairy heifer and beef cattle, in general, when compared with Tier 2 and 3 enteric $\mathrm{CH}_{4}$ factors, Tier 1 enteric $\mathrm{CH}_{4}$ factors produced a considerable over-prediction of $\mathrm{CH}_{4}$ emissions for young animals (less than 1 year old), with exception for dairy bulls, for which Tier 1 was similar to Tier 2 (because they were managed under intensive feeding regimes). On the contrary, for animals of over 1 year age, Tier 1 enteric $\mathrm{CH}_{4}$ factors were smaller than Tier2/3 enteric $\mathrm{CH}_{4}$ factors, except for dairy heifers of over 2 years for which Tier 1 was larger than Tier 2/3 (due to low growth rates). Similar results were also obtained for $\mathrm{CH}_{4}$ emissions from manure management.

Table 1 Tier 1 versus Tiers 2 and 3 methane emission factors for enteric fermentation and manure management

\begin{tabular}{|c|c|c|c|c|c|c|c|c|c|c|}
\hline \multirow[b]{2}{*}{ Species } & \multirow[b]{2}{*}{ Age } & \multirow[b]{2}{*}{ Category } & \multicolumn{3}{|c|}{ Enteric $(\mathrm{kg} / \mathrm{y})$} & \multicolumn{2}{|c|}{ As $\%$ of Tier 1} & \multicolumn{2}{|c|}{ Manure (kg/y) } & \multirow{2}{*}{$\begin{array}{r}\mathrm{T} 2 / \mathrm{T} 1 \\
(\%)\end{array}$} \\
\hline & & & Tier 1 & Tier 2 & Tier 3 & Tier 2 & Tier 3 & Tier 1 & Tier 2 & \\
\hline Dairy cow & Milking + dry & & 117 & 106.8 & 109.5 & 91 & 94 & 21 & 19.4 & 92 \\
\hline \multirow{6}{*}{ Beef cattle } & $<1$ year & Dairy steer/heifer & 57 & 34.4 & 37.0 & 60 & 65 & 6 & 4.0 & 66 \\
\hline & $<1$ year & Dairy bull & 57 & 57.5 & 50.2 & 101 & 88 & 6 & 5.3 & 89 \\
\hline & $<1$ year & Suckler & 57 & 32.0 & 29.1 & 56 & 51 & 6 & 4.6 & 77 \\
\hline & 1-2 year & Dairy steer/heifer & 57 & 65.6 & 66.5 & 115 & 117 & 6 & 6.8 & 114 \\
\hline & 1-2 year & Suckler & 57 & 63.6 & 64.0 & 112 & 112 & 6 & 6.6 & 110 \\
\hline & $>2$ year & Suckler cow & 57 & 56.9 & 59.1 & 100 & 104 & 6 & 6.1 & 101 \\
\hline \multirow{6}{*}{ Dairy heifer } & $<1$ year & Holstein-Friesian & 57 & 29.7 & 33.3 & 52 & 59 & 6 & 3.7 & 61 \\
\hline & $<1$ year & Cross breeding & 57 & 27.3 & 30.2 & 48 & 53 & 6 & 3.3 & 55 \\
\hline & $1-2$ year & Holstein-Friesian & 57 & 64.5 & 69.5 & 113 & 122 & 6 & 7.2 & 119 \\
\hline & $1-2$ year & Cross breeding & 57 & 57.5 & 61.5 & 101 & 108 & 6 & 6.3 & 105 \\
\hline & $>2$ year & Holstein-Friesian & 57 & 50.3 & 52.9 & 88 & 93 & 6 & 5.4 & 91 \\
\hline & $>2$ year & Cross breeding & 57 & 49.7 & 52.4 & 87 & 92 & 6 & 5.4 & 90 \\
\hline \multirow{3}{*}{ Sheep } & $<1$ year & Lamb & 8 & 6.6 & 4.6 & 83 & 58 & 0.19 & 0.08 & 41 \\
\hline & $>1$ year & Ewe & 8 & 8.0 & 10.5 & 100 & 131 & 0.19 & 0.16 & 85 \\
\hline & Replacement & & 8 & 7.5 & 7.5 & 94 & 94 & 0.19 & 0.13 & 70 \\
\hline
\end{tabular}

Conclusions For both enteric fermentation and manure management, in comparison with Tier 2/3 emission factors, Tier 1 default factors over-estimated $\mathrm{CH}_{4}$ emissions for dairy cows, young cattle and sheep, while under-predicted $\mathrm{CH}_{4}$ emissions for beef cattle, heifers and sheep at age between 1 and 2 years old. This indicates that the development of national $\mathrm{CH}_{4}$ emission inventories from the Tier 1 method can result in considerable and systematic errors.

Acknowledgements This study was funded by Department of Agriculture and Food (ROI) and DARDNI.

IPCC. 2006. Guidelines for National Greenhouse Gas Inventories. In:www.ipccnggip.iges.or.jp/public/2006gl/index.html. 